Cornell Law Library

Scholarship@Cornell Law: A Digital Repository

Cornell Law Faculty Publications

Faculty Scholarship

$12-2002$

\title{
Do Antitakeover Defenses Decrease Shareholder Wealth? The Ex Post/Ex Ante Valuation Problem
}

Lynn A. Stout

Cornell Law School,1s483@cornell.edu

Follow this and additional works at: http://scholarship.law.cornell.edu/facpub

Part of the Corporation and Enterprise Law Commons

\section{Recommended Citation}

Stout, Lynn A., "Do Antitakeover Defenses Decrease Shareholder Wealth? The Ex Post/Ex Ante Valuation Problem" (2002). Cornell Law Faculty Publications. Paper 760.

http://scholarship.law.cornell.edu/facpub/760

This Article is brought to you for free and open access by the Faculty Scholarship at Scholarship@Cornell Law: A Digital Repository. It has been accepted for inclusion in Cornell Law Faculty Publications by an authorized administrator of Scholarship@Cornell Law: A Digital Repository. For more information, please contact jmp8@cornell.edu. 


\title{
Do Antitakeover Defenses Decrease Shareholder Wealth? The Ex Post/Ex Ante Valuation Problem
}

\begin{abstract}
Lynn A. Stout*
Over the past two decades, academics have generated a large empirical literature examining whether antitakeover defenses like poison pills or staggered board provisions decrease the wealth of shareholders in target corporations. Many studies, however, rely primarily on ex post analysis-they consider only how antitakeover defenses (ATDS) influence shareholder wealth after the corporation has been formed and, in some cases, long after the ATD was adopted. This Response argues that it may be impossible to fully understand the purpose or effects of ATDs without also considering their ex ante effects. In particular, ATDs may increase net target shareholder wealth ex ante if they encourage nonshareholder groups to make extracontractual investments in corporate team production. The Response reviews recent empirical evidence suggesting that shareholders do in fact perceive ATDs as beneficial ex ante. It also explores some implications for contemporary corporate scholarship and the attempt to measure the wealth effects of antitakeover rules.
\end{abstract}

INTRODUCTION 845

I. SOME THEORETICAL EX ANTE BENEFITS OF ATDs ....................................... 847

II. THE PLAUSIBILITY OF EX ANTE BENEFITS ............................................ 850

III. EMPIRICAL EVIDENCE OF EX ANTE BENEFITS ......................................... 853

IV. The Ex Ante/Ex Post Valuation Problem: Some Cautions for

ATD OBSERVERS

\section{INTRODUCTION}

Consider the following scenario. The directors of company $A$ learn that company $B$ is about to make a tender offer for $100 \%$ of $A$ 's shares. The offer is for cash, at a price that represents a fifty percent premium over the price at which $A$ 's shares have been trading in the market. In response, $A$ 's directors

* Professor of Law, University of California at Los Angeles School of Law. I would like to thank Iman Anabtawi, Stephen Bainbridge, Steve Banks, Lucian Bebchuk, Margaret Blair, John Coates, Ron Gilson, Bill Klein, Lynn LoPucki, Douglas Olin, Leo Strine, Guhan Subramanian, and Randall Thomas for their comments on earlier drafts. 
adopt an antitakeover defense commonly known as a "poison pill." Because the pill can only be disarmed by the vote of a majority of $A$ 's directors, $B$ must win control of $A$ 's board before it can proceed with its hostile offer. This is made far more difficult by the fact that $A$ 's corporate charter includes a second antitakeover device, a "staggered board" clause that allows directors to serve three-year terms and provides that only a third face reelection in any single year. To win control, $B$ accordingly must win not one but two proxy contests, spaced a year apart.

Faced with $A$ 's antitakeover provisions and its board's resistance, $B$ decides to withdraw its tender offer. $B$ 's plans to acquire $A$ evaporate--and with them, the $A$ shareholders' opportunity to sell at a premium.

Commentators often cite this sort of scenario as evidence that antitakeover defenses (ATDs) that impede hostile bids reduce the wealth of target shareholders. ${ }^{1}$ Indeed, the notion that ATDs destroy shareholder wealth has inspired an entire genre of legal scholarship attacking various types of ATDs found in modern corporate by-laws, charters, and statutes. ${ }^{2}$ A characteristic example can be found in a recent study by Professors Lucian Bebchuk, John Coates, and Guhan Subramanian. ${ }^{3}$ Analyzing a five-year sample of hostile takeover bids, the authors conclude that ATDs of the sort adopted by company $A$ (a staggered board combined with a poison pill) make hostile deals significantly less likely to succeed, and reduce the average returns of target shareholders in the nine months following a hostile bid by eight to ten percent when compared to the returns to shareholders in target firms that lack these ATDs. ${ }^{4}$ From this, the authors conclude that the combination of a poison pill and a staggered board has a "negative wealth effect," and that Delaware corporate law ought to be changed to preclude target managers from using such an ATD mix. ${ }^{5}$

Yet did the shareholders of target company $A$ really lose money as a result of the firm's ATDs? Although on first inspection the answer to this query seems rather obviously to be yes-if ATDs had not allowed $A$ 's board to defeat

1. See, e.g., Lucian Arye Bebchuk, John C. Coates IV \& Guhan Subramanian, The Powerful Antitakeover Force of Staggered Boards: Theory, Evidence, and Policy, 54 STAN. L. REv. 887 (2002).

2. For recent examples, see id; Lucian Arye Bebchuk, The Case Against Board Veto Power in Corporate Takeovers, 69 U. CHI. L. REV. 973 (2002); John C. Coates IV \& Guhan Subramanian, $A$ Buy-Side Model of M\&A Lockups: Theory and Evidence, 53 STAN. L. REV. 307 (2000); Robert B. Thompson \& D. Gordon Smith, Toward A New Theory of the Shareholder Role: "Sacred Space" in Corporate Takeovers, 80 TEX. L. REv. 261 (2001). For earlier versions of this type of argument, see, for example, Frank H. Easterbrook \& Daniel R. Fischel, The Proper Role of a Target's Management in Responding to a Tender Offer, 94 HARV. L. REv. 1161 (1981); Ronald J. Gilson, The Case Against Shark Repellent Amendments: Structural Limitations on the Enabling Concept, 34 STAN. L. REV. 775 (1982).

3. See Bebchuk et al., supra note 1 .

4. See id. at 950 .

5. More particularly, they recommend that target managers be precluded from maintaining a pill after losing a first proxy contest against a hostile bidder. See id. at 944-45. 
$B$ 's takeover attempt, $A$ 's shareholders could have sold their shares at a substantial premium-this Response argues that the relationship between ATDs and shareholder wealth is more complex. In particular, the notion that discouraging premium bids necessarily reduces target shareholder wealth relies entirely on ex post analysis. In other words, it considers only how ATDs affect target shareholders after an offer is made. But this is not the only time at which one can, or should, consider the influence of ATDs on shareholder wealth. To the contrary, it may be impossible to fully understand the purpose or effects of antitakeover rules without also examining them from an ex ante perspective.

This Response offers such an ex ante analysis. It considers not only how ATDs influence shareholder returns when a hostile bid is made, but also how they influence shareholder returns well before then-indeed, how they influence returns from the moment they are put into place, as early as when the corporation is first created. Viewed from an ex ante perspective, there is both substantial theoretical reason and substantial empirical evidence to believe that in many cases ATDs do not reduce target shareholders' wealth, but increase it. What's more, ATDs accomplish this by doing exactly what critics condemn them for doing-making takeovers less likely.

\section{SOME THEORETICAL EX ANTE BENEFITS OF ATDS}

To understand how target firm shareholders can benefit from ATDs, we must begin by considering what it takes to build a successful public corporation. Shareholders alone cannot make a company. Other groupsincluding most obviously executives and other employees-also make essential contributions. Modern corporate production accordingly is a form of team production. Just as it takes two people to move a large sofa, with both parties' efforts indispensable to the job, it takes inputs and efforts from financial investors (including shareholders and creditors) and human capital investors (including executives and rank-and-file employees) to build a successful firm. ${ }^{6}$

Why do nonshareholder groups contribute to corporate production? Part of the reason can be found in the explicit contracts these groups enter into with firms. For example, executives and other employees work in part because they are entitled to some contractually defined mix of wages, deferred compensation, and perquisites.

Many firms, however, also rely on "implicit" contracts-informal and legally unenforceable understandings. For example, employees often believe

6. See Margaret M. Blair \& Lynn A. Stout, A Team Production Theory of Corporate Law, 85 VA. L. REV. 247 (1999). For simplicity, this Response focuses on the team contributions of shareholders on the one hand, and employees on the other. However, other groups also can make essential contributions to team production in public firms. See id. at 250,278 (noting that other groups, including creditors and the broader community, may make investments in corporate team production); see also Lynn A. Stout, Bad and Not-SoBad Arguments for Shareholder Primacy, 75 S. CAL. L. REV. 1189, $1195-96$ (2002) (same). 
that if they stay with the firm, perform well, and the firm prospers, they will receive in the future not just the benefits they are entitled to under their explicit employment contracts (when these exist) but also raises, promotions, and some job security. What's more, firms often encourage such beliefs. By signaling to their hires that if they remain loyal and do a good job they will receive discretionary future rewards beyond those mandated by the firm's explicit contracts, firms can inspire employees from the shop floor to the executive suite to work harder and to invest more in firm-specific human capitalknowledge, skills, and relationships that are valuable to the firm, but worthless to any other potential employer. Implicit contracts thus serve both sides to the deal.

As common as these understandings are in the business world, they rarely appear as formal contracts that can be enforced in a court. The reason lies in the contracting problems that are endemic to team production under conditions of uncertainty. ${ }^{7}$ It is impossible, for example, to anticipate in advance every contingency that might affect team members (if a competitor fails and the firm as a result enjoys an increase in revenues, should the employees get a raise or should the shareholders get a dividend?), or to prove in a court of law that a team member has failed to perform according to the terms of the implicit bargain (did the CEO truly devote her best efforts to the firm?).

The observation that implicit contracts are not enforced in courts naturally raises the question of where they are enforced. Enforceability matters, because otherwise team members might try to opportunistically renege on their implicit commitment by shirking or expropriating wealth from the team. One alternative might be to leave enforcement of implicit contracts up not to judges, but to another, more informed referee-the corporation's board of directors.

I have explored this idea in detail in other writings with Margaret Blair, in which we suggest that public corporations raise team production problems that cannot be resolved satisfactorily through explicit contracting or other common solutions. ${ }^{8}$ We argue that as an alternative, participants in public firmsincluding most obviously shareholders, creditors, executives, and rank-and-file

7. See generally Blair \& Stout, supra note 6 (discussing contracting problems). To gain a quick sense of the scope of these problems, consider the difficulties involved even in drafting a simple contract between two workers who want to move a sofa together. If the two workers agree ex ante to share profits equally, both have incentive to shirk, and try to leave the other to carry more than half the load. Conversely, if they agree to wait until the sofa has been moved and split the profits according to who worked hardest, they are likely to waste valuable time and effort arguing and squabbling (rent seeking), with no obvious solution. Perhaps, if they could find a machine that could accurately measure exactly how much effort each expends, they could draft an explicit contract that precludes shirking and rent seeking. But such measurement devices do not exist even for the simple task of moving a sofa, much less for the far more complex task of building a successful corporation.

8. See Blair \& Stout, supra note 6; see also Margaret M. Blair \& Lynn A. Stout, Director Accountability and the Mediating Role of the Corporate Board, 79 WASH. U. L.Q. 403 (2001). 
employees-address their contracting problems and mutual vulnerability by giving up control over the firm's assets and earnings to a board of directors. ${ }^{9}$ The board in turn is charged with running the firm in a fashion that not only increases the wealth of the firm's shareholders, but also provides extracontractual benefits to other corporate participants. ${ }^{10}$

This description of the board's role as a "mediating hierarch" is consistent with the way modern corporate law actually works. Although a number of commentators have argued over the years that directors ought to consider only shareholders' interests in running the firm, ${ }^{11}$ as an empirical matter modern corporate law grants boards of public firms tremendous freedom to use their control over the firm to benefit nonshareholder constituencies, often at the shareholders' apparent expense. ${ }^{12}$ Indeed, ATDs themselves evidence this pattern.

Granting directors such freedom can impose costs on shareholders ex post, because shareholders who cede control of the firm to a board inevitably run the risk the board will use that authority to serve other corporate participants' interests. This may be especially likely when board members develop personal ties of empathy and loyalty to the firm's executives and employees. Nevertheless, shareholders can benefit from "tying their own hands" and giving up control over the firm in this fashion. They can benefit because, ex ante, they get something more valuable in return-the ability to recruit and retain talented

9. There are other substitutes for judicial enforcement to encourage team members to honor their implicit agreements. For example, in small firms, or those with few shareholders, corporate participants who know each other and interact face-to-face can rely to some degree on mutual trust and trustworthiness to discourage selfish opportunism. See Margaret M. Blair \& Lynn A. Stout, Trust, Trustworthiness, and the Behavioral Foundations of Corporate Law, 149 U. PA. L. REV. 1735, 1799-1807 (2001) (discussing role of trust in small firms). In other contexts, market forces, including concern for business reputation, can police against exploitive behavior among team members.

10. Although encouraging team production may be one of the more important functions of the board, it should be noted that boards can serve other functions as well, for example, efficient decisionmaking.

11. See, e.g., Frank R. EAsterbrook \& Daniel R. Fischel, The Economic STRUCTURE OF CORPORATE LAW 36-39 (1991) (arguing that firms should be run to maximize shareholder wealth); Milton Friedman, The Social Responsibility of Business Is to Increase Its Profits, N.Y. TIMES, Sept. 13, 1970, $\S 6$ (Magazine), at 32 (arguing that corporate managers' sole focus should be shareholders' profits).

12. See Blair \& Stout, supra note 6, at 290-315 (describing doctrines that grant directors such authority); Stout, supra note 6, at 1202-04 (same); see also Stephen M. Bainbridge, Director Primacy in Corporate Takeovers: Preliminary Reflections, 55 STAN. L. REV. 791 (discussing how directors and not shareholders control firms). Although directors as a legal matter control the firm and its assets, in theory shareholders enjoy some control over the directors through their power to elect or remove members of the board. In practice, obstacles to collective action in large public firms make it extremely unlikely that the shareholders can oust incumbent board members except in extreme cases. As a result shareholders' voting rights leave directors a good deal of leeway to provide extracontractual benefits to other corporate participants. Blair \& Stout, supra note 6, at 309-15. 
managers and employees, and to inspire them to far greater effort and investment in the firm than any formal contract could. ${ }^{13}$

This analysis does not imply that antitakeover defenses always create wealth for shareholders. As I discuss in detail later, there may be cases in which boards adopt ATDs that reduce shareholder wealth ex post without providing any offsetting ex ante benefit, or where ATDs that were once wealthenhancing become inefficient and obsolete. ${ }^{14}$ Team production analysis does imply, however, that ATDs can increase net shareholder wealth in some, and possibly many, situations.

\section{The Plausibility of Ex Ante Benefits}

As the previous Part observes, theoretical support exists for the proposition that corporate governance rules that grant directors discretion to favor nonshareholder groups-including but not limited to ATDs-can provide shareholders with ex ante benefits that outweigh their ex post costs. Indeed, while team production analysis offers many fresh insights into this notion, ${ }^{15}$ the basic idea is neither novel nor particularly controversial. It appears in the economic literature on takeovers since at least the $1980 \mathrm{~s},{ }^{16}$ and has played a prominent role in several recent law review articles on corporate governance as well. 17

13. Employees and executives (as well as shareholders) are likely to recognize that board members develop ties of empathy and loyalty. They are also likely to calculate that such ties make boards more willing to provide them with future discretionary benefits, like raises and job security, than shareholders would be. As a result, they may be more willing to enter implicit understandings with the firm and to rely on those understandings by making the types of extracontractual investments that can be essential to a company's success. Thus, the extracontractual benefits enjoyed by executives and other employees in modern firms are not necessarily evidence of inefficient "agency costs" or "managerial slack," but may instead represent the justifiable and efficient allocation of a portion of the rents created through successful team production to valuable team members.

14. See infra text accompanying notes $43-48$.

15. For example, team production analysis sheds light on the nature of the firm, see Blair \& Stout, supra note 6, at 271-76 (discussing firm as a nexus of firm-specific commitments by team members), the terms of the "implicit contract" entered between the firm and team members such as managers and employees, id. at 277-78 (describing contract as an agreement to participate in a process of goal setting and dispute resolution under the ultimate authority of a board of directors), and the rationales underlying a variety of rules of corporate law, $i d$. at 290-315 (describing how team production analysis helps to explain rules of legal personality, fiduciary duty, and shareholder voting).

16. See, e.g., Charles R. Knoeber, Golden Parachutes, Shark Repellents, and Hostile Tender Offers, 76 AM. ECON. REv. 155, 161 (1986) (arguing that ATDs benefit shareholders ex ante by helping to enforce implicit contracts entered between the firm and its managers that encourage the latter's investment in firm specific human capital); Andrei Shleifer \& Lawrence H. Summers, Breach of Trust in Hostile Takeovers, in CORPORATE TAKEOVERS: CAUSES AND CONSEQUENCES 33, 37-42 (Alan J. Auerbach ed., 1988) (same).

17. See, e.g., Blair \& Stout, supra note 6; Bruce Chapman, Trust, Economic Rationality, and the Corporate Fiduciary Obligation, 43 U. TORONTO L.J. 547 (1993); G. 
The contemporary literature on ATDs nevertheless often overlooks or glosses over the possibility that antitakeover rules might provide shareholders with such ex ante benefits. ${ }^{18}$ This may not be a harmless oversight. There is reason to believe that ex ante benefits from ATDs are not only possible in theory, but also plausible in a variety of common business situations.

Perhaps the most obvious is the case of the start-up venture. When a firm is first formed, ATDs can play an important role in encouraging team production. This is because the firm's survival may depend at this early stage on retaining and motivating a skilled, dedicated, and specialized management team. Indeed, the venture's success may hinge on the ideas and entrepreneurial

Mitu Gulati, William A. Klein \& Eric M. Zolt, Connected Contracts, 47 UCLA L. REV. 887 (2000); Thomas A. Smith, The Efficient Norm for Corporate Law: A Neotraditional Interpretation of Fiduciary Duty, 98 MicH. L. REv. 214 (1999). For an earlier and pioneering argument in this vein, see John C. Coffee, Jr., The Uncertain Case for Takeover Reform; An Essay on Stockholders, Stakeholders, and Bust-Ups, 1988 WIS. L. REV. 435.

18. See, e.g., Bebchuk et al., supra note 1; Guhan Subramanian, The Influence of Antitakeover Statutes on Incorporation Choice in the 1990s: Evidence on the "Race" Debate and Antitakeover Overreaching, 151 U. PA. L. REv. 1795 (2002). For an older example of this omission, see EASTERBROOK \& FISCHEL, supra note 11.

When ATD critics do discuss the possibility of ex ante benefits, they often do not address the possibility of benefits from encouraging investment in team production, but instead focus on, and usually dismiss, the argument that ATDs protect shareholders when the market inefficiently underprices their shares. See, e.g., Robert Daines \& Michael Klausner, Do IPO Charters Maximize Firm Value? Antitakeover Protections in IPOs, 17 J.L. ECoN. \& ORG. 83, 88-89, 99-106 (2001); see also id. at 106-07 (addressing and rejecting the additional argument that ATDs allow top managers to extract "private benefits," such as the "psychic benefits" of maintaining family control of a corporation).

An important exception to this pattern can be found in a recent article by Lucian Bebchuk that addresses in some detail the possibility that ATDs promote team production. See Bebchuk, supra note 2, at 1021-27. Bebchuk ultimately rejects this idea, however, on the theory that, as a practical matter, boards are not likely to be good agents for stakeholders because boards' and stakeholders' interests are not closely aligned. As a result, Bebchuk argues, director primacy is not a good way to promote team production.

Margaret Blair and $I$ have argued at length elsewhere that directors may in fact be quite good agents for nonshareholder groups. See Blair \& Stout, supra note 6, at 305-09, 315. To summarize our argument, board members who want to keep their positions have an interest in seeing their firms grow and prosper, in avoiding risk, and in ensuring that control remains in their own hands. Although this agenda can conflict with shareholders' interests, it often is aligned with the interests of creditors and employees, who also benefit from empire-building and lose from high-risk strategies that threaten the loss of their firm-specific investments. In the takeover context, incumbent directors' interests may be especially well-aligned with the firm's incumbent executives, who constitute one of the most important stakeholder groups involved in corporate production and who likely would prefer to avoid board changes that threaten their own positions.

Boards accordingly may be better agents for stakeholders than Bebchuk suggests. Nevertheless, they still may not be very good agents, as Blair and I concede. See id. at 28384 (describing mediating hierarchy as second-best solution). The observation that director primacy is a poor governance system does not, however, imply that a better system is available. To paraphrase Winston Churchill, director primacy may be the worst possible form of corporate governance, except for all the alternatives. 
efforts of a single individual. Due to the uncertainty that surrounds new ventures, it may also be especially difficult to design formal contracts that provide sufficient incentive for executives to invest in skill, dedication, and specialization. As a result, investors in some cases may calculate that the most cost-effective available means of encouraging managers to employ their best efforts and invest in firm-specific human capital is to implicitly promise them future benefits if things go well, protect them from being ousted by putting in place a board of directors whom the managers trust, and insulate that board from the threat of a hostile takeover by adopting antitakeover defenses.

ATDs can benefit shareholders in more mature firms as well. Common business practices suggest that the extracontractual inputs of executives and other employees are often viewed as vital to business success even in very large firms. (Otherwise, it is hard to explain why these firms expend such effort to recruit and screen potential hires, and to train and motivate individuals already hired, rather than simply designing an optimal contract and taking aboard anyone willing to sign on the dotted line.) Yet the opportunity to sell at a premium can present shareholders with a tempting ex post opportunity to extract wealth from executives and lower-level employees whenever these groups rely on implicit contracting to even a modest degree, especially when employee-related expenses are a larger line item on the income statement than reported profits, as is the case at most firms.

A simple example illustrates the plausibility of such situations. ${ }^{19}$ Suppose that in the past, target company $A$ encouraged its executives and lower-level employees to work harder than their formal contracts could force them to work, and to invest more in firm-specific human capital, through an informal understanding that if the firm prospered they would receive future extracontractual benefits in the form of job security, increased compensation and perquisites, and wages higher than they could earn if they abandoned their firm-specific investments (which by definition cannot be sold to other potential employers) and sought employment elsewhere. Now the future has arrived, and the total cost of these extracontractual benefits amounts to five percent of $A$ 's annual employee-related expenses. Suppose also that $A$ has annual sales of $\$ 110,000$, employee-related expenses of $\$ 100,000$, and, for simplicity's sake, no other expenses. Annual profits accordingly are $\$ 10,000$.

Now bidder corporation $B$ arrives on the scene, and wants to purchase $A$ in order to renege on the implicit understanding that $A$ 's employees are to enjoy extracontractual benefits in return for their past efforts and firm-specific investments. By reducing or even eliminating these benefits, $B$ could bring annual expenses down from $\$ 100,000$ to $\$ 95,000$. Because of the disproportionate relationship between expenses and profits, this modest five percent reduction would increase $A$ 's annual profits from $\$ 10,000$ to $\$ 15,000$.

19. This example is based on a similar one presented in Shleifer \& Summers, supra note 16 , at 36 . 
That increase alone would justify $B$ 's paying a fifty percent premium for $A$ 's stock-a considerably larger premium than is actually paid in the typical hostile takeover. ${ }^{20}$

As this example demonstrates, one cannot simply reject as empirically unlikely the possibility that even large takeover premiums may benefit target shareholders primarily by imposing costs on other corporate participants, especially managers and other employees. Indeed, target directors often express just such fears when confronted by hostile bids. ${ }^{21}$

Similarly, one cannot dismiss a priori the argument that ATDs that impose costs on target shareholders ex post may nevertheless increase net shareholder wealth by providing even larger benefits ex ante. ATDs provide ex ante benefits because they encourage nonshareholders to make extracontractual investments that may be vital to building a successful firm. If $A$ 's employees had believed that its board not only could, but had to, sell the company to any bidder who offered even a modest premium-the sort of legal reform scholars who condemn ATDs often recommend $22-A$ 's executives might have been far more reluctant to commit their careers to the firm, and its rank-and-file far less willing to work extra hours and invest in firm-specific contacts and skills. In other words, without its ATDs, corporation $A$ might never have become a successful firm (and an attractive acquisition target) in the first place.

We do not need to rely only on such observations, however, to find evidence that ATDs provide significant ex ante benefits to shareholders. There is more direct empirical support available. This support can be found in shareholders' ex ante behavior.

\section{EMPIRICAL EVIDENCE OF EX ANTE BENEFITS}

One of the most puzzling characteristics of ATDs (puzzling at least from an ex post perspective) is that they are often put in place at quite an early stage in the corporate lifecycle. For example, two recent studies-including one by John Coates-found that in the late 1990s, depending on the time period observed, between forty-four percent and eighty-two percent of firms that "went public" included staggered board provisions in their charters at the time of the initial public offering (IPO). ${ }^{23}$

20. See Bebchuk et al., supra note 1, at 926 tbl.2 (finding $37 \%$ average premium in hostile deals in recent five-year sample).

21. See, e.g., Cheff v. Mathes, 199 A.2d 548, 550-53 (Del, Ch. 1964) (discussing how target's directors resisted hostile bidder while citing employees' interests).

22. See, e.g., Easterbrook \& Fischel, supra note 2.

23. See, e.g., John C. Coates IV, Explaining Variation in Takeover Defenses: Blame the Lawyers, 89 CAL. L. REV. 1301, 1376 (2001) (finding that percentage of IPO firms with staggered boards rose from $34 \%$ in early 1990 s to $82 \%$ in 1999); Daines \& Klausner, supra note 18 , at 96 tbl.2 (finding that $43.5 \%$ of firms that went public between 1994 and 1997 had staggered boards). Coates's 2001 article concluded that his findings were "consistent with 
This pattern is significant. Any member of the investing public who is considering buying shares in the IPO can readily determine that the charter contains an ATD. Presumably, if the investor thinks the ATD will reduce her future returns, she will protect herself by discounting the price she is willing to pay for the firm's shares. Corporate promoters who retain ATDs at the IPO stage accordingly should be cheating only themselves. Nevertheless, promoters frequently put ATDs in the charters of firms that are going public, at a time when they have every interest in catering to potential investors. This finding strongly suggests that investors do not object to and may even prefer the ex ante adoption of ATDs at many firms.

A similar pattern emerges from studies of firms' incorporation behavior. Some states' laws offer the boards of target companies far more protection from hostile bids than other states' do. ${ }^{24}$ If antitakeover laws reduced shareholders' returns without providing any offsetting benefit, one would think investors would penalize corporate promoters who incorporate in states with a strong antitakeover bias, and promoters as a result would have incentive to avoid these states. Nevertheless, states with relatively strong antitakeover laws do better at attracting new firms and at retaining old ones than states whose laws seem more "shareholder friendly" from an ex post perspective. ${ }^{25}$

Both sorts of findings demonstrate that early in the corporation's lifecycle, shareholders have a "revealed preference" (to employ the language of economics) for at least some degree of antitakeover protection. In other words, shareholders act as if they value corporate governance rules that insulate boards from hostile takeovers.

It is possible that shareholders' revealed preferences do not reflect their actual preferences. Bebchuk, Coates, and Subramanian offer this argument briefly in their article, when they note that shareholders seem to tolerate ATDs at the IPO stage but suggest in a footnote that this might be due to imperfections in the IPO market. ${ }^{26}$ Other imperfections in the incorporation process may similarly prevent shareholders from punishing promoters who choose states with inefficient antitakeover rules. The IPO evidence and the

[antitakeover] defenses being generally optimal at the IPO stage." Coates, supra, at 1383.

24. For example, some states have passed statutes that explicitly validate poison pills, that prevent hostile bidders from voting with shares they acquire until they pass an ownership threshold of 20 to $50 \%$, or that preclude hostile acquirers from entering a wide range of transactions with the acquired firm without the target board's prior approval. See Subramanian, supra note 18, at 1828 tbl.3 (comparing various state antitakeover statutes).

25. See, e.g., Lucian Bebchuk \& Alma Cohen, Firms' Decisions Where to Incorporate (John M. Olin Program in Law \& Econ., Working Paper No. 352, 2002), available at http://www.law.harvard.edu/programs/olin_center/papers/pdf/352.pdf; Lucian Bebchuk, Alma Cohen \& Allen Ferrell, Does the Evidence Favor State Competition in Corporate Law, 90 CAL. L. Rev. (forthcoming 2002); cf. Subramanian, supra note 18, at 1844 (noting that there is migration towards states with typical antitakeover provisions, but some evidence of migration away from states with "severe" antitakeover laws).

26. Bebchuk et al., supra note 1, at 943 n. 158. 
incorporations evidence also are consistent with an alternative and much simpler explanation, however. Perhaps shareholders actually do value corporate governance rules that insulate boards from hostile takeovers.

In fact, shareholders' revealed preference for antitakeover rules appears to be just one facet of a much larger pattern: shareholders' preference for ceding control over their investments, and over the firm's assets and outputs, to a board. 27 In a sense, investors' penchant for "tying their own hands" in this fashion is apparent from the very choice of a corporation as an organizational form. Governance by a board of directors is a fundamental feature of the public corporation. The Delaware Code expressly provides that " $\mathrm{t}] \mathrm{he}$ business and affairs of every corporation organized under this chapter shall be managed by or under the direction of a board of directors." 28

Of course, in theory corporate promoters are free to modify this rule (for example, by adding a charter provision that prohibits the board from adopting a poison pill without shareholder approval). ${ }^{29}$ In practice, entrepreneurs avoid the sorts of charter "reforms" scholars often argue would benefit shareholders. ${ }^{30}$ To the contrary, when promoters modify the default rules of director authority, they almost always move in the opposite direction, adding provisions that insulate directors from shareholders' command and control even more than the default rules of corporate law do. ${ }^{31}$

An extreme example of this phenomenon-and of shareholders' apparent enthusiasm for it - can be found in a recent study of firms that announced plans to create a second class of stock with limited voting rights. ${ }^{32}$ Because managers generally retain the stock with the superior voting rights in such dualclass firms (and with it, the ability to choose who sits on the board), dual-class recapitalization represents the epitome of public shareholder disenfranchisement. Nevertheless, the study found that firms that adopted dualclass structures enjoyed abnormally positive stock market and operating returns in the four years following the announcement. ${ }^{33}$

27. See Stephen M. Bainbridge, Director Primacy: The Means and Ends of Corporate Governance, $97 \mathrm{Nw}$. U. L. REV. (forthcoming 2002) (discussing this pattern); Blair \& Stout, supra note 6 , at 322-23 (finding that the prevalence of public corporations "suggests there may be significant economic advantages to the public corporation form in spite of (or, as we suggest, because of) the requirement of ceding control to an independent board of directors").

28. DEL. CODE ANN. tit. $8, \S 141$ (a) (2002).

29. $I d$.

30. See, e.g., Coates, supra note 23, at 1397 (observing that explicit charter prohibitions against poison pills "are so rare as to be almost nonexistent for research purposes").

31. See id. at 1376 (observing that incidence of classified board provisions has increased steadily over the 1990 s to over $80 \%$ of IPOs).

32. Valentin J. Dimitrov \& Prem Jain, Dual Class Recapitalization and Managerial Commitment: Long-Run Stock Market and Operating Performance (Dec. 11, 2001), available at http://papers.ssrn.com/ abstract $=297792$.

33. Id. at 24-25. Interestingly, this result was driven primarily by the positive 
Thus, if we step back from the relatively narrow issue of ATDs to observe modern corporate governance from a greater distance, an interesting pattern emerges. Shareholders seem to prefer governance arrangements that require them to give up a rather large degree of control to a board-even when this means the board later can use its authority to benefit nonshareholders.

This pattern directly undermines the claim that corporate governance provisions that protect director fiat (including but not limited to ATDs) necessarily reduce shareholder wealth. It also implies that any analysis of ATDs that looks only at their ex post effects may be seriously incomplete. Here lies a significant problem for contemporary takeover scholarship.

\section{The Ex Ante/Ex Post Valuation Problem: SOME CAUTIONS FOR ATD OBSERVERS}

Over the past two decades, economists, law professors, and business scholars have developed something of a cottage industry publishing empirical studies concluding that one type of ATD or another supposedly is destructive of shareholder wealth. ${ }^{34}$ Team production analysis suggests, however, that these studies tell us far less about how ATDs affect shareholder wealth than first impressions suggest. This is because many of the empirical studies rely entirely upon ex post analysis. Put differently, they examine only the ex post cost variable in the ATD cost-benefit equation, while ignoring the ex ante benefit variable.

The Bebchuk, Coates, and Subramanian study of the staggered board/pill combination illustrates this type of partial analysis. The authors find the combination of a staggered board and a poison pill nearly doubles the odds that a target firm will fend off a hostile bid, reducing target shareholders' ex post returns by eight to ten percent in the nine months following the appearance of a hostile bidder. ${ }^{35}$ From this, the authors conclude that the staggered board/poison pill combination reduces shareholder wealth, and corporate law accordingly ought be modified to prevent its use. ${ }^{36}$

The empirical findings presented by Bebchuk, Coates, and Subramanian do a nice job of undermining the argument that ATDs increase target shareholders' ex post returns by giving target boards bargaining leverage to demand higher

abnormal returns enjoyed by the large subset of firms whose controlling managershareholders did not list their voting shares on a stock exchange: This subset saw abnormal returns of $40 \%$ over the four years following the dual-class announcement. Id. at 5, 24 . Because such arrangements commit manager-shareholders to the firm by making it more difficult for them to "cash out," one explanation for the authors' findings might be that dual class capitalization "can enhance managers' incentives to make firm-specific investments in their human capital that add to firm value." Id . at 1 .

34. See supra notes 1-5 and accompanying text; infra notes 39-44 and accompanying text.

35. Bebchuk et al., supra note 1 , at 950.

36. Id. at 936-37, 944-50. 
premiums from hostile bidders. ${ }^{37}$ But they provide a questionable foundation for the authors' broader policy conclusions. If ATDs provide shareholders with significant ex ante benefits - as both theory and evidence suggest-the fact that they also sometimes impose ex post costs tells us almost nothing about whether ATDs on balance are good or bad for target shareholders, much less whether they are good or bad for society as a whole. ${ }^{38}$

For related reasons, we cannot safely draw conclusions about the value of antitakeover defenses by listening to the complaints shareholders voice about those defenses when potential bidders appear. For example, ATD critics often point to institutional shareholder proposals to eliminate existing ATDs (e.g., by amending the firm's charter to destagger the board) as evidence that shareholders view ATDs as wealth-destroying. 39 Team production analysis suggests, however, that such strategies may reflect nothing more than an attempt to expropriate wealth from nonshareholder groups that have made extracontractual investments in team production in the belief that a hostile change in control is unlikely. While it is hardly surprising that shareholder groups sometimes try to "have their cake and eat it too," such after-the-fact opportunism should not be taken as evidence that ATDs do not serve shareholders quite well ex ante.

Similarly, a focus on the ex post/ex ante measurement problem highlights the danger of making policy judgments based on "event studies" that measure how stock prices respond when firms adopt new ATDs or when states pass new antitakeover statutes.40 A number of these studies have found that the adoption of certain ATDs, or the passage of certain types of antitakeover laws, is associated with modest declines in the market price of the stock of the firm or firms affected. ${ }^{41}$ These results are cited as support for the claim that ATDs reduce shareholder wealth. 42

37. Id. at 936-37.

38. Although scholars often focus on how ATDs affect target shareholders, takeovers obviously affect other groups as well. For example, an acquisition that provides a premium to target shareholders may harm the bidding firm's shareholders if the bidder pays too high a price due to overoptimism (the "winner's curse"), or may impose offsetting costs on nonshareholder groups such as employees, managers, and creditors.

39. See Bebchuk et al., supra note 1, at 891-92 (discussing shareholder proposals); Michael Klausner, Institutional Shareholders' Split Personality on Corporate Governance: Active in Proxies, Passive in IPOs (John M. Olin Program in Law \& Econ., Working Paper No. 225, 2001), available at http://papers.ssm/com/abstract=292083 (same).

40. See generally John C. Coates IV, Takeover Defenses in the Shadow of the Pill: A Critique of the Scientific Evidence, 79 TEX. L. REv. 271, 280-97 (2002) (discussing and citing numerous event studies of adoption of poison pill); Subramanian, supra note 18, at 1829-30 (discussing and citing numerous event studies on the adoption of antitakeover laws by state legislatures).

41. See, e.g., Coates, supra note 40 , at 280-86 (discussing results of event studies of poison pills); Subramanian, supra note 18, at 1829-30 (discussing results of event studies of antitakeover legislation).

42. See, e.g., Daines \& Klausner, supra note 18, at 89-91 (noting methodological 
By their nature, however, event studies examine only how antitakeover rules affect shareholder wealth "midstream"-after the corporation has been formed, after shareholders have purchased its stock, and after employees and managers have made many of their extracontractual investments. At this point, adding an ATD easily can reduce net shareholder wealth, because enhanced antitakeover protection may not efficiently encourage future investment in team production, but instead simply provide a windfall to current managers in the form of more perquisites and greater job security than they expected when they made their initial investment decisions. The possibility of such a midstream wealth transfer does not, however, imply either that ATDs do not benefit shareholders at the IPO/incorporation stage, or even that midstream ATDs are wealth-reducing from a social perspective. (Shareholders' losses may be offset by other corporate stakeholders' gains.)

The bottom line is that, once we consider the possibility that antitakeover rules provide ex ante benefits to shareholders by encouraging team production and implicit contracting, it becomes almost impossible to evaluate the general wisdom of such provisions from a purely ex post perspective. It also becomes clear that the extensive and still-growing empirical literature measuring ATDs' ex post effects tells us far less than is often assumed.

This is not to say that all ATDs are shareholder wealth-maximizing, or that ex post effects should be ignored. In particular, ex post analysis may be especially helpful in understanding and identifying two common situations in which ATDs may reduce net shareholder wealth.

The first, already mentioned, involves ATDs that are put into place midstream and without effective shareholder consent. For example, as Bebchuk, Coates, and Subramanian point out, one cannot safely assume that the staggered board/poison pill combination serves shareholders' ex ante interests in the many cases where shareholders accepted a staggered board provision before poison pills had became so widespread that investors could be expected to anticipate their use, and the pill was subsequently adopted by unilateral board action. ${ }^{43}$ Similarly, firms can acquire new antitakeover defenses through legislation that changes the law of the state in which the firm is incorporated. Shareholders also have no voting rights in this situation. ${ }^{44}$ As a result, directors can use such midstream changes to protect themselves from the discipline of the market for corporate control, even when this does not provide shareholders with ex ante benefits sufficient to outweigh the ex post costs.

problems with event studies while citing them in support of the claim that antitakeover rules reduce shareholder wealth); Subramanian, supra note 18, at 1829-30 (same).

43. See Bebchuk et al., supra note 1, at 940-44.

44. It is also plausible that, even when the adoption of an ATD requires nominal shareholder approval (e.g., when amending the charter to add a staggered board), lack of information, rational apathy, and other obstacles prevent shareholders from exercising their franchise effectively in this as in many other matters. 
It is important to bear in mind that this does not mean that all midstream ATDs are inefficient. For example, sometimes a midstream ATD may allow the firm to retain a highly valued management team that would otherwise leave the firm or withhold its best efforts. This possibility may explain, for example, the otherwise puzzling findings that shareholders often approve charter amendments to adopt a dual-class structure, and that firms that undergo dualclass recapitalization enjoy abnormal positive returns in the stock market and in operating results. ${ }^{45}$ When a midstream ATD is added without a shareholder vote and is accompanied by a decline in stock value, however, it seems reasonable to assume the ATD reduces shareholder wealth.

The second situation in which ATDs may be inefficient arises not when the firm's governance rules change midstream, but when the governance rules remain fixed while circumstances change. As noted earlier, there is reason to believe that ATDs can play an especially important role in encouraging team production early in the corporate lifecycle. 46 Yet as a firm matures and becomes more stable, and as its day-to-day operations become more routine, the identity and contributions of specific employees may become less important. Simultaneously, decreased uncertainty may make formal contracting easier. ATDs that were essential for the firm's very survival during the start-up phase accordingly can become unimportant or even dysfunctional over time.

This raises the question of why corporate promoters do not commonly modify ATDs with "sunset provisions" that automatically eliminate the ATD after a period of time (for example, after ten years). At least two explanations come to mind. First, given the uncertainty that surrounds the creation of any new business, corporate promoters may be reluctant to try to predict exactly when in the future ATDs might become dispensable. Second, because of the time value of money, future losses from ATDs that become inefficient only after years or decades have passed may be so small, in terms of present value, that they can safely be ignored. Of course, when the future eventually arrives, the cost of an inefficient ATD can be substantial. This last point argues for some mechanism for invalidating ATDs when it can be demonstrated that they are necessary neither to perform past implicit contracts, nor to encourage future investment in team production.

The observation that ATDs can increase shareholder wealth accordingly does not imply that all ATDs are efficient at all times. ATDs adopted midstream and without effective shareholder consent can be wealth-destroying, and even ATDs that were efficient when first adopted can become obsolete. There is much to be learned from ex post analysis that helps to identify

45. See supra text accompanying notes 32-33.

46. See supra text accompanying notes 18-26. 
particular cases in which antitakeover defenses do more to destroy wealth than to create it. ${ }^{47}$

Yet it remains hazardous to evaluate the categorical wisdom of antitakeover rules by looking only at ex post results. Judging the value of whole classes of ATDs by measuring their costs to shareholders in the form of lost premiums, while ignoring their benefits in terms of encouraging investment in team production, amounts to trying to calculate the sum of two numbers by counting only one. By overlooking the benefit portion of the cost-benefit calculus, this partial-measurement approach inevitably risks producing misleading results.

The pressures that drive the ATD literature toward such partial analysis are understandable. It can be far more difficult to gauge the benefits ATDs provide target shareholders by protecting and encouraging team production over long periods, than it is to measure the takeover premiums shareholders sometimes lose in the actual event of a hostile bid. 48 This is true even though, due to the time value of money, ATDs' ex ante benefits may far outweigh their ex post costs. For example, an ATD that allows a start-up firm that would otherwise fail to survive and thrive over a period of years by retaining and motivating its managers has tremendous value compared to the one-time cost its shareholders might incur in the distant future if the ATD precludes them from selling to a hostile bidder. Nevertheless, it is hard to assess what might have happened if

47. For example, event studies that show that firms that adopt ATDs without a shareholder vote experience stock-price declines, see supra note 41 , provide evidence that such midstream adoptions reduce shareholder wealth. Of course, shareholders' losses must be offset against other groups' gains before one can conclude the change was inefficient.

48. In theory, one might be able to measure the ex ante value of ATDs by creating a sample of firms about to go public that already have elected to put ATDs in their charters. Presumably, these are the firms whose promoters view ATDs as wealth-enhancing. One could then divide the sample into two subgroups, and instruct the firms in one subgroup (the test group) to eliminate their ATDs while the second subgroup (the control group) retained their ATDs. Then one could follow the two subgroups over time in a longitudinal study of operating and stock-price performance.

As a practical matter, this sort of test is impossible. Researchers cannot tell corporate promoters what to do, and even if a foundation were willing to give a grant large enough to allow researchers to bribe a test group of firms into dropping their ATDs, there would remain problems of self-selection and how to control for the wealth advantages enjoyed by the firms that take the bribes.

Put differently, at present the most feasible way to test what is optimal for firms ex ante is to simply observe what they actually do ex ante, at the IPO stage and the incorporation stage, when corporate participants have the greatest incentive and the greatest opportunity to select optimal governance rules. As noted earlier, most firms ex ante in fact seem to prefer antitakeover rules. See supra text accompanying notes 23-26. Of course, while studies of the adoption of ATDs at the IPO/incorporation stage allow us to draw conclusions about whether or not shareholders at this point expect ATDs to provide them with future benefits, they do not establish whether and to what extent those anticipated benefits eventually materialize. 
the firm had not been able to employ ATDs, and relatively easy to measure the lost premium.

Salience problems may also prompt many observers to overlook ATDs' ex ante benefits. When ATDs do what they are supposed to do-when they allow directors to provide extracontractual benefits to nonshareholder groups such as executives and employees, who in return make extracontractual contributions to team production that benefit shareholders-corporations function smoothly and effectively. As a result, the role played by ATDs in such firms receives little attention from outsiders. In contrast, both media coverage and corporate case law tend to focus on the relatively small number of dysfunctional firms whose shareholders, managers, and board members are in obvious conflict. 49 Commentators whose opinions of ATDs are shaped by observations drawn from this subset might easily conclude that antitakeover defenses do more harm than good.

To those who actually participate in corporations, however, the potential advantages of ATDs are more visible. This may explain why corporate insiders themselves-including not only directors and executives, but also shareholders-often behave as if they believe the advantages of ATDs outweigh their disadvantages. ${ }^{50}$ Even as the scholarly literature condemning antitakeover rules steadily expands, corporate promoters continue to incorporate in states with relatively strict antitakeover laws, to retain ATDs in charters during the IPO process, and to reject charter provisions that might restrict boards' use of poison pills and other familiar defenses. Investors continue to buy stock in such firms. This evidence underscores the hazards of evaluating antitakeover rules according to their ex post costs without also accounting for their ex ante benefits.

49. For example, the Bebchuk, Coates, and Subramanian Study focuses on how ATDs affected shareholder returns at a subset of 92 firms that received hostile bids over a five-year period. Bebchuk et al., supra note 1, at 926 tb1.2. During the same period, ATDs were in place at thousands of other firms that were not targeted for a hostile bid. Id. at 895 (citing studies finding that the majority of large public firms had staggered boards during this time).

50. See supra text accompanying notes 23-27. This may also explain why, as Coates has observed, academics tend to oppose the use of antitakeover defenses while business lawyers and judges support them. See Coates, supra note 40, at 273 ("[A]cademics generally have taken a dim view of takeover defenses, and practicing lawyers have generally supported defenses in advising clients, with judges and legislators siding more with practitioners than with academics."). 
*** 